\title{
SCIENCE AND FAITH
}

GIR WILLIAM BRAGG's Riddell Memorial $S_{\text {Lecture on "Science and Faith", delivered }}$ before the University of Durham at King's College, Newcastle-upon-Tyne, on March 7, which has now been published*, will interest all who wish for harmony between the different spheres of human thought.

The 'natural knowledge' which has grown so amazingly in the last three centuries is not so distinct in character from other knowledge that it is to be considered entirely by itself.

"The whole knowledge at our disposal is far greater than our modern science, as the whole is greater than the part. It includes the observations of countless generations of men, their experiences of life and the record of their thoughts thereon and the comments of their interpreters and lawgivers, the histories of the actions of nations and individuals especially in relation to the faiths on which they have acted, all in fact that men have learnt since they first began to learn."

Modern science is only a part of this mass of knowledge. If it is a new chapter in our book of knowledge, does it throw light on the chapters that have gone before? Is it going to help men towards a solution of the great problem of the choice of an attitude to life? Men have adhered to certain faiths: does science affect their present choice of a faith? Such are the questions raised by Sir William Bragg in his lecture.

"I would describe Science", writes Sir William, "as a collection of observations of Nature. There is an old word 'observables' which aptly describes the facts that the scientist is on the look-out for. Science observes the observables, tries to see what is noteworthy and records it. Gradually a mass of knowledge is accumulated which is sufficiently stable and reliable, so that it is worthy of study and can be used safely."

The man of science as he works must draw temporary conclusions from what he sees because in so doing he finds guidance in the next effort of discovery. If he made no attempt to plan his work he would lose himself in a mass of uncoordinated facts ; hence he must try to find correlations, rules and laws. To grasp what he has already got would be impossible unless he did this.

"He therefore makes hypotheses. But it is to be observed that all such hypotheses are tentative,

- Science and Faith. By Sir William Bragg. (University of Durham Riddell Memorial Lectures, Thirteenth Series, delivered before the University of Durham at King's College, Newcastle-upon-Tyne, on March 7, 1941.) Pp. 24. (London: Oxford University Press, 1941.) 18. 6d. net. and are to be amended constantly as knowledge grows. There is no finality in these attempts to draw conclusions. Some are more enduring than others, but it can never be said of any law formed and used by the scientist that it is good for all time."

Sir William Bragg supplies three notable instances of universally accepted and to all appearance permanently secure hypotheses which in due course had to be revised in view of new knowledge. Such were the atomic theory of matter and the Newtonian theory of gravitation. Yet in neither case, Sir William points out, was the work of those who formed the superseded theory wasted or wholly invalidated. Chemists can still work with the atomic theory, knowing that the chances of any atom breaking down while in their hands are so small as to be negligible. And though Einstein has shown that there is a point beyond which Newton's theory begins to lack perfection, the astronomer's work is not affected.

The third instance of a scientific theory which had to be modified is a fine example of this need to abstain from dogmatism, which seience teaches continuously. In his "History of the Inductive Sciences" Whewell spoke of the undulatory theory of light as the perfect example of a true and complete theory since it not only explained all that was known but also continually predicted new phenomena which were then found to exist.

"Yet there came a sudden end to this certainty when the properties of $\mathbf{X}$-rays were made plain, and it became certain that they and light itself had corpuscular as well as undulatory properties. When, however, the work of the long years of development of the wave theory was reconsidered, it was found to be still well done and without flaw : the light really was a wave motion. Yet the new discoveries cannot be readily explained on any but a corpuscular hypothesis.

"Here then is a case where not only was the accepted and trusted theory in need of modification, but there is the added complexity that two hypotheses which are both supported by quantities of excellent proof seem to be mutually exclusive. There is as yet no simple explanation, in the sense that no clue has been found which would lead simply from one hypothesis to the other. A mathematical formula can be found which covers the two cases, and that is all."

There is thus a position "which seems nonsensical and is nevertheless true". This surely is a test case of science's dislike of dogmatism. 
Passing on to the other side of his subject, Sir William Bragg accepts the definition of faith found in Hebrews xi, 1, that it is "the substance of things hoped for, the evidence of things not seen", which he calls "an unforgettable sentence obviously full of earnestness and meaning". The Greek would appear to convey the meaning that faith consists in regarding as already actual, things which are only as yet hoped for, and in an assurance that things not yet seen are nevertheless real. The writer of Hebrews supplies a number of instances of persons who "died in faith", that is, lived until death without surrendering this attitude of mind and will. Thus Sir William's interpretation of the sentence is sound, namely, that the writer's faith, "the faith which he held himself and preached to others, was a hypothesis so firmly held and trusted that he would and did stake his life upon it".

Hypothesis is therefore integral alike to science and to faith, and so forms a link between the two, and this is being more generally recognized on both sides.

"It seems to me that in recent years the way of the scientist and the way of the seeker for a good way of life have come to have more features in common than in the past, more than is generally recognized. If the scientist was ever unduly dogmatic he has ceased to be so: this one-time selfassertion at a time within living memory was in no small degree a weapon of offence and defence which he felt himself compelled to assume. In part it was a mistake of his own making. I should think that the theologian's dogma is now becoming more and more like the scientist's hypothesis, so probable of course that he accepts it and acts upon it always. If the theologian says that I am not justified in my statement, I shall still suspect that the disagreement is subject to a misunderstanding."

His point that hypothesis is of the essence of science and faith alike is of such importance that perhaps it deserves to be examined more closely than the limits on his space enabled Sir William Bragg to do. Are the two hypotheses, that of science and that of faith, the same in kind, or is a radical distinction to be drawn between them? The scientific hypothesis can be proved or disproved here and now by referring the matter to a controlled experiment; the appeal is to sense-experience and to 'facts'. But that the religious hypothesis cannot always be so proved is indicated by what the writer of Hebrews says of his exemplars of religious faith, "These all died in faith, not having received the promises". These people, some of whom he says died in torments, never received confirmation of their faith-at least not in this world. Fiven the last recorded words of the
Founder of Christianity were "My God, my God, why hast thou forsaken me?"

It is, of course, true that the Christian 'way of life' can be tested in practice as to whether or no it 'works'. This is clearly what Sir William Bragg has in mind when he writes:

"Science is experimental, moving forward step by step, making trial and learning through success and failure. Is not this also the way of religion, and especially of the Christian religion? The writings of those who preach that religion have from the very beginning insisted that it is to be proved by experience. If a man is drawn towards honour and courage and endurance, justice, mercy, and charity, let him follow the way of Christ and find out for himself that it leads where he would go. No findings of science hinder him in that way, nor do they give any direct proof that it is the right one to follow."

Of course a pragmatic test of this sort must not be pressed to carry a weight of proof of which it is incapable. It can never establish the Christian religion as a body of principles with metaphysical validity. But is such a thing necessary? Science can dispense with metaphysics, so why not religion? But can science dispense with metaphysics altogether? Are there not involved certain "absolute presuppositions", as Prof. R. G. Collingwood calls them, which are of a metaphysical nature, and without which science could not stir an inch ? For example, the idea of the uniformity of Nature, the conception of the rationality of things, and the idea of causation itself? Hume long ago claimed to have shown that the validity of the causal relation is not founded in experience, since experience only shows us that one event follows another, and does not exhibit to us the inner necessity of their union. In short, the idea of causation is a hypothesis, rather different from the type of hypothesis illustrated by Sir William Bragg, since science cannot afford to change it, but perhaps not dissimilar from the type of hypothesis, or "absolute presupposition", which religion seems to need.

Of course the man of science is quite justified in taking the idea of causation and other similar ideas for granted; if he did not, his researches into natural happenings would never begin, still less arrive anywhere. And perhaps the mistake the exponents of religion make is not in having metaphysical doctrines, but in placing them on the threshold of religion, where they often prove an obstacle to people trying to enter the house. It may be that Sir William Bragg has this kind of obstacle in mind when he says towards the close of his lecture :

"I am not sufficiently informed to know how all types of mind are affected by the demand for the 
absolute acceptance of definite items of faith as a preliminary condition to progress. I believe I can safely say that to many minds this is an impossible demand. Conviction of the truth of any faith, so far as a man can measure the truth, is to be gained by practice, and it is here that the scientist finds an illustration in his own work. Every man, in the circle in which he finds himself, it may be a small circle, his means may be small also, can try the Christian way, and discover for himself and acquire his own convictions. He tests his faith. He has ever in front of him the hope that he will by doing his service play his part in binding the community together."

Speaking of his own youth, Sir William writes :

"What we boys asked was the meaning of the word 'believe' when it so often laid down a condi- tion which must be satisfied before a man could be 'saved'. '. . . they that have done evil into everlasting fire. This is the Catholick Faith: which except a man believe faithfully he cannot be saved'. Had we passed the test, or had we not? We were terrified by the threatened consequences. To the youth daily instructed in the need for accuracy and the careful interpretation of words, this was indeed a dreadful saying. If anyone took them at their face value, drew them towards him and explored their significance he would necessarily be driven mad, unless indeed he was deprived of feeling by some drug."

It is a pity that the zeal of the theologian should have converted his "absolute presuppositions" into a barbed-wire entanglement menacing the pilgrim who would explore his temple.

\section{PSYCHOLOGICAL EFFECTS OF AIR RAIDS}

\section{By Dr. Robert H. Thouless}

\section{UNIVERSITY OF CAMBRIDGE}

$\mathrm{T}^{\mathrm{H}}$ HE experiences of war through which Great Britain is passing pose many psychological problems of urgent practical importance. Knowledge has been gained in many directions which can now be put to practical use. Detailed studies of evacuation, such as the Cambridge Evacuation Survey, the findings of which have recently been published*, enable us to assess both the general success of the evacuation policy and the particular steps which must be taken to avoid failure in special cases. The problems of shelter life have been studied by medical men, by psychiatrists, by shelter lecturers, and by psychologists who have lived in shelters because they. have been bombed out of their homes, and it is now possible to gain some idea of the iitricate social psychological problems of shelter life. The effects on morale of air-raid experiences have been studied both by academic psychologists and by mass observation, and it is to be hoped that their findings may be made use of by those Government departments responsible for civil morale. These problems were considered at a discussion of the problems of air-raid shelters, evacuation and the effects of air raids at a general meeting of the British Psychological Society on July 26.

Psychologists and psychotherapists have approached the problem of shelter conditions from

* The Cambridge Evacuation Survey. Edited by Dr. Susan Isaacs. Pp. ix +236 . (London: Methuen and Co., Ltd., 1941.) 8s. 6d. net. many different angles; the problems for future research have been clarified and some knowledge has been gained which can be made the basis for practical proposals. The transfer of authority attitudes from within the family to the officials of shelter groups (shelter marshals, etc.) was suggested as an important factor in determining whether defence mechanisms against raid shock would be adequate. It was noticed that a greater sense of security was given by underground shelters than by surface shelters and that the presence of crowds and of the various shelter officials also reduced anxiety. For both of these reasons, individual Anderson shelters were generally neglected and communal underground shelters were preferred. Of those who went to communal shelters, 95 per cent were reported to have got adequate sleep ; weight lost at home was regained and neurotic symptoms disappeared. It seems clear, therefore, that the provision of communal shelters rather than of individual ones is, in general, the best policy.

Studies of those who went through air raids as children in the War of 1914-18 showed the importance of adult attitudes of mental calm as a means of protecting children against raid anxiety, and also the reduction of fear by the provision of suitable spontaneous activities. While lectures on such subjects as first aid have been provided for adults and adolescents in some areas, 